\title{
PENGARUH PENAMBAHAN TEPUNG UBI JALAR UNGU (Ipomea batatas L. var. ayamurasaki) TERHADAP KARAKTERISTIK HEALTH-PROMOTING YOGURT
}

\section{Effects of Purple Sweet Potato (Ipomea batatas L. var. ayamurasaki) Additions on the Characteristic of Health-Promoting Yogurt}

\author{
Gusti Chandra Rizki ${ }^{1)}$, Komang Ayu Nocianitri ${ }^{2)}$, I Made Sugitha ${ }^{2)}$ \\ ${ }^{1}$ Mahasiswa Jurusan Ilmu dan Teknologi Pangan, Fakultas Teknologi Pertanian, Unud \\ ${ }^{2}$ Dosen Jurusan Ilmu dan Teknologi Pangan, Fakultas Teknologi Pertanian, Unud \\ Kampus Bukit Jimbaran, Badung-Bali
}

\begin{abstract}
This research aims to identify the effect of adding purple sweet potato flour to the characteristics of health-promoting yogurt and to identify the right concentration of purple sweet potato flour to produce health-promoting yogurt with the best characteristics. This research used a Randomized Block Design (RBD) of the addition of purple sweet potato flour with the concentration of $0 \%, 2 \%, 4 \%, 6 \%, 8 \%$. Each treatment was repeated 3 times, resulting in 15 experimental units. The data were then Analyzed of Variance (ANOVA) method and if the treatment had an effect on the variable, the Duncan Multiple Range Test (DMRT) were performed. The results showed purple sweet potato flour has significant effect to lactic acid total, $\mathrm{pH}$, antioxidant activity, color, texture, and taste of health-promoting yogurt and did not significantly affect LAB total, hedonic taste, aroma, and overall acceptance. The addition of $8 \%$ purple sweet potato flour resulted in the best characteristic under the following criteria: $1.23 \%$ of lactic acid total, 3.73 of $\mathrm{pH}, 90.33 \%$ of antioxidant activity, $13.19 \mathrm{log} \mathrm{CFU} / \mathrm{ml}$ of LAB total, pink color and indefferent color, thick texture rather like, sour taste rather like, flavor and overall acceptance rather like.
\end{abstract}

Keywords: health-promoting yogurt, purple sweet potato flour, antioxidant.

\section{PENDAHULUAN}

Yogurt merupakan produk yang diperoleh dari fermentasi susu dengan menggunakan bakteri Lactobacillus bulgaricus dan Streptococcus thermophillus dan atau bakteri asam laktat (BAL) lain yang sesuai, dengan/atau tanpa penambahan bahan pangan lain dan bahan tambahan pangan yang diizinkan (Anon., 2009). Menurut Winarno, dkk. (2003), S. thermophilus dan L. bulgaricus tidak dapat digolongkan sebagai bakteri probiotik karena tidak mampu melewati saluran usus manusia. Helferich dan Westhoff (1980) menyatakan bahwa bakteri asam laktat pada yogurt telah mati pada usus kecil, maka keuntungan yang diberikan bagi kesehatan saluran pencernaan manusia juga akan berkurang.

$$
\text { Yogurt yang mengandung health- }
$$
promoting culture disebut sebagai health-

*Korespondensi Penulis:

E-mail: gusticr11@gmail.com ${ }^{1)}$ 
promoting yogurt. Health-promoting culture merupakan kultur bakteri yang bersifat probiotik, yakni dapat meningkatkan keseimbangan mikroflora usus sehingga bermanfaat bagi kesehatan apabila dikonsumsi. Penambahan kultur yang berbeda baik tunggal maupun campuran seperti Lactobacillus, Bifidobacterium, dan Enterococcus dapat meningkatkan sifat fungsional yogurt apabila dikonsumsi (Tamime dan Robinson, 2007).

\section{Lactobacillus rhamnosus SKG34 (L.} rhamnosus SKG34) adalah salah satu strain probiotik potensial yang dapat dikembangkan (Sujaya, dkk., 2009). Keunggulan L. rhamnosus SKG34 yakni dapat menurunkan kolesterol, meningkatkan kadar HDL, serta dapat berkolonisasi pada saluran pencernaan manusia (Nocianitri, dkk., 2017; Pratiwi, dkk., 2013). Penelitian yang dilakukan oleh Yuliansyah (2014) melaporkan bahwa $L$. rhamnosus SKG34 baik sebagai starter tunggal maupun dikombinasikan dengan $L$. bulgaricus dan $S$. thermophilus dapat menghasilkan yogurt dengan kualitas yang tidak berbeda.

Yogurt yang difermentasi menggunakan kultur tunggal cenderung memiliki tekstur yang kurang padat sehingga diperlukan penambahan padatan (Solid Non Fat) yang dapat memperbaiki tekstur akhir yogurt (Siregar, dkk., 2014). Tamime dan Robinson (2007) menyatakan bahwa bahan padatan (Solid Non Fat) yang dapat ditambahkan dapat berupa susu skim, buttermilk, bubuk kasein, atau berupa padatan bukan protein susu (non-milk protein solid) seperti campuran sukrosa dan gelatin, kacang-kacangan dan biji-bijian karena mengandung protein yang cukup tinggi, atau ubi-ubian karena mengandung karbohidrat yang berfungsi sebagai bahan pengisi dan pembentuk tekstur. Sifat fisik yogurt seperti viskositas atau konsistensi sangat penting dan secara umum semakin tinggi tingkat bahan padat dalam campuran yogurt, semakin besar viskositas atau konsistensi dari produk akhir (Tamime dan Robinson, 2007). Patrignani, dkk., (2006) menjelaskan bahwa yogurt (dengan penambahan 3\% susu skim bubuk) yang lebih padat, konsisten, kental, dan kohesif dianggap memiliki kualitas terbaik, karena lebih diterima oleh konsumen dan tidak memerlukan bahan tambahan seperti gum atau bahan pengental lainnya.

Ubi jalar ungu merupakan salah satu jenis ubi jalar yang banyak ditemui di Indonesia (Lingga, 1995). Sebagian besar umbi ubi jalar terdiri atas air dan karbohidrat. Siregar, dkk., (2014) menjelaskan bahwa karbohidrat pada ubi jalar ungu dapat digunakan sebagai bahan baku untuk diversifikasi pangan yang mengandung probiotik. Keunggulan lain yang dimiliki beberapa varietas ubi jalar adalah kandungan 
antioksidan yang tinggi, seperti pada ubi jalar ungu (Hasyim dan Yusuf, 2008).

Ubi jalar ungu banyak diolah menjadi produk setengah jadi yakni dalam bentuk tepung. Tepung ubi jalar ungu memiliki ukuran partikel yang kecil (60-80 mesh) sehingga dapat bercampur secara homogen dengan partikel susu, sehingga tepung ubi jalar ungu dapat digunakan sebagai bahan baku dan bahan substitusi untuk industri pangan olahan (Koswara, 2013). Menurut Rahmawati, dkk., (2015), medium fermentasi ubi jalar ungu (bentuk tepung dalam air) lebih cepat meningkatkan jumlah sel bakteri probiotik. Perlu dilakukan penelitian tentang penambahan tepung ubi jalar pada pembuatan health-promoting yogurt untuk menghasilkan karakteristik terbaik.

\section{METODE PENELITIAN}

\section{Tempat dan Waktu}

Penelitian ini telah dilaksanakan di UPT. Laboratorium Terpadu Biosains dan Bioteknologi Universitas Udayana dan Laboratorium Biokimia dan Nutrisi Fakultas Teknologi Pertanian Universitas Udayana pada bulan Agustus sampai dengan Desember 2018.

\section{Bahan dan Alat}

Bahan yang digunakan dalam penelitian ini adalah susu pasteurisasi merk Greenfield, ubi jalar ungu (Ipomea batatas L.) var. Ayamurasaki, starter Lactobacillus rhamnosus SKG34, air, aquades, deMann Rogossa Sharpe Broth (MRSB), American Bacteriological Agar, Alkohol 70\%, NaCl $0,85 \%$, larutan lugol, kristal violet, pewarna safranin, $\mathrm{H}_{2} \mathrm{O}_{2} 3 \%$, gliserol $30 \%, \mathrm{NaOH} 0,1$ $\mathrm{N}$, Indikator Phenolphtalein (PP), larutan 1,1diphenyl-2-picrylhydrazyl (DPPH), Methanol $95 \%$.

Alat yang digunakan dalam proses pembuatan health-promoting yogurt dengan penambahan tepung ubi jalar ungu adalah refrigerator (Toshiba Glacio), incubator (Memmert), neraca analitik (Shimadzu AUX 220), baskom, water bath (NVC Thermologic), gelas beaker (Pyrex), pengaduk, termometer, stopwatch, toples kaca volume $250 \mathrm{ml}$, sendok, pisau, Oven (Memmert), ayakan 80 mesh, tray, batang pengaduk, vortex (Labnet), $\mathrm{pH}$ meter (Martini Instrument MI 105), tabung reaksi (Pyrex), pipet mikro (Genex Beta), pipet volume (Pyrex), labu ukur (Pyrex), kapas, kaca objek, kantong plastik, bunsen, alat titrasi (Pyrex), cawan petri (PetriQ), Erlenmeyer (Pyrex), magnetic stirrer (Fisher Scientific), laminar flow (JSR JSCB-900SB), microtube (Eppendorf), tip kuning ukuran $100 \mu \mathrm{l}$, dan tip biru ukuran $1 \mathrm{ml}$, freezer (GEA), spektrofotometer (Thermo Scientific Evolution 201).

\section{Rancangan Percobaan}

Rancangan yang digunakan pada

penelitian ini adalah Rancangan Acak 
Kelompok (RAK) yang terdiri dari 5 perlakuan penambahan tepung ubi jalar ungu yaitu: P1 (0\%), P2 (2\%), P3 (4\%), P4 (6\%), dan P5 (8\%). Masing-masing diulang sebanyak 3 kali sehingga diperoleh 15 unit percobaan. Data yang dihasilkan kemudian dianalisis dengan analisis ragam pada program SPSS dan apabila terdapat pengaruh perlakuan terhadap variabel yang diamati, maka dilanjutkan dengan uji Duncan (Gomes dan Gomes, 1995).

\section{Pelaksanaan Penelitian}

Proses pembuatan health-promoting yogurt dengan penambahan tepung ubi jalar ungu meliputi beberapa tahap, yaitu:

1. Pembuatan Tepung Ubi Jalar Ungu

Ubi jalar ungu dikupas lalu dilakukan pencucian lalu dipotong setebal $1 \mathrm{~cm}$ kemudian dilakukan pengukusan selama 7 menit. Ubi jalar ungu kemudian dikecilkan ukurannya menggunakan pemarut lalu dikeringkan menggunakan oven dengan suhu $60^{\circ} \mathrm{C}$ selama 12 jam. Ubi jalar yang telah kering (dapat dipatahkan) dihaluskan dan diayak dengan ayakan berukuran 80 mesh untuk menghasilkan tepung ubi jalar ungu (Husnah, 2010).

\section{Penyegaran dan Konfirmasi Isolat}

Bakteri Lactobacillus rhamnosus SKG34 dilakukan penyegaran dengan cara diambil $0,1 \mathrm{ml}$ stok isolat yang disimpan dalam gliserol $30 \%$ pada suhu $-20^{\circ} \mathrm{C}$ dan diinokulasi pada media $5 \mathrm{ml}$ MRS Broth selama 24 jam dengan suhu $37^{\circ} \mathrm{C}$ (Dede, 2018). Hasil positif ditunjukkan dengan munculnya kekeruhan pada media (Yuliansyah, 2014). Uji konfirmasi isolat dilakukan setelah penyegaran, melalui uji katalase, pewarnaan gram dan uji gas (Suryani, dkk. 2010).

\section{Pembuatan Starter Health-Promoting Yogurt \\ Pembuatan starter diawali dengan} persiapan isolat L. rhamnosus SKG34, dan kemudian dilakukan penyegaran. Dilakukan proses sentrifugasi untuk memisahkan supernatan dengan media, lalu dilakukan pencucian dengan saline sebanyak 3 kali (Dede, 2018). Susu sapi segar merk Greenfield dipasteurisasi pada suhu $80^{\circ} \mathrm{C}$ selama 15 menit, kemudian didiamkan hingga suhu susu mencapai $45^{\circ} \mathrm{C}$. Susu ditempatkan pada wadah inkubasi dan dilakukan penambahan isolat sebanyak $0,1 \% \mathrm{v} / \mathrm{v}$. Dilakukan inkubasi pada suhu $43^{\circ} \mathrm{C}$ selama 24 jam, kemudian didinginkan dalam refrigerator, untuk menghentikan proses fermentasi (Fraizer dan Westhoff, 1998).

\section{Pembuatan Health-Promoting Yogurt}

Tahapan proses pembuatan healthpromoting yogurt mengacu pada metode Fraizer dan Westhoff (1998) yang telah dimodifikasi meliputi : pengukuran dan pencampuran bahan, pemanasan, penambahan starter, inkubasi, dan 
pendinginan. Alat-alat yang digunakan untuk proses pembuatan health-promoting yogurt disterilisasi terlebih dahulu.

Tepung ubi jalar ungu diukur sesuai dengan perlakuan dan kemudian dicampurkan ke dalam $100 \mathrm{ml}$ susu hingga homogen, kemudian dipasteurisasi pada suhu $80^{\circ} \mathrm{C}$ selama 15 menit. Campuran susu ditempatkan pada jar kaca volume $125 \mathrm{ml}$ yang telah

\section{HASIL DAN PEMBAHASAN}

Hasil uji konfirmasi isolat Lactobacillus rhamnosus SKG34 setelah dilakukan penyegaran sel dapat dilihat pada Tabel 1.

Hasil uji konfirmasi terhadap stok kultur Lactobacillus rhamnosus SKG34 memberikan hasil negatif pada uji gas dan uji katalase serta memberikan hasil berwarna ungu pada uji cat gram yang berarti bahwa bakteri ini termasuk kelompok bakteri gram positif. Lactobacillus rhamnosus SKG34 merupakan jenis BAL homofermentatif dimana jenis BAL ini menghasilkan asam laktat sebagai produk utama dari fermentasi gula. Jenis BAL homofermentatif memberikan hasil negatif pada uji gas.

Hasil pewarnaan gram Lactobacillus rhamnosus SKG34 menunjukkan warna ungu diberikan kode sampel sesuai perlakuan dan kemudian didinginkan dengan cara didiamkan sampai mencapai suhu $45^{\circ} \mathrm{C}$, kemudian ditambahkan starter sebanyak 5\% b/v. Campuran susu diinkubasi dalam inkubator pada suhu $43^{\circ} \mathrm{C}$ selama 24 jam.

Tabel 1. Hasil uji konfirmasi stok kultur Lactobacillus rhamnosus SKG34 Uji Konfirmasi Hasil

\begin{tabular}{ll}
\hline Uji Katalase & $(-)$ Negatif \\
Uji Gas & $(-)$ Negatif \\
Cat Gram & Gram positif (Ungu) \\
Uji Morfologi & Batang, kurus dan \\
& panjang \\
\hline
\end{tabular}

yang berarti bahwa bakteri ini termasuk dalam kelompok bakteri gram positif, hal ini dikarenakan bakteri tersebut memiliki kandungan lipid yang rendah, sehingga dinding sel bakteri akan lebih mudah terdehidrasi akibat perlakuan dengan alkohol yang menyebabkan ukuran pori-pori sel menjadi lebih kecil dan daya permeabilitasnya berkurang sehingga zat warna kristal violet yang merupakan zat warna utama tidak dapat keluar dari sel (Pelczar,1986).

Hasil analisis total asam laktat, $\mathrm{pH}$, aktivitas antioksidan, dan total BAL healthpromoting yogurt dapat dilihat pada Tabel 2 . 
Tabel 2. Nilai rata-rata total asam laktat, $\mathrm{pH}$, aktivitas antioksidan, dan total BAL dari healthpromoting yogurt dengan penambahan tepung ubi jalar ungu.

\begin{tabular}{ccccc}
\hline $\begin{array}{c}\text { Penambahan } \\
\text { Tepung Ubi } \\
\text { Jalar Ungu }\end{array}$ & $\begin{array}{c}\text { Total Asam } \\
\text { Laktat } \\
(\%)\end{array}$ & $\mathrm{pH}$ & $\begin{array}{c}\text { Aktivitas } \\
\text { Antioksidan }(\%)\end{array}$ & $\begin{array}{c}\text { Total BAL } \\
\text { (Log Cfu/ml) }\end{array}$ \\
\hline P1 (0\%) & $0,70 \pm 0,05 \mathrm{c}$ & $4,25 \pm 0,02 \mathrm{a}$ & $14,51 \pm 0,21 \mathrm{e}$ & $11,95 \pm 0,43 \mathrm{a}$ \\
P2 (2\%) & $0,71 \pm 0,04 \mathrm{c}$ & $3,85 \pm 0,01 \mathrm{~b}$ & $38,39 \pm 1,19 \mathrm{~d}$ & $12,89 \pm 0,52 \mathrm{a}$ \\
P3 (4\%) & $1,08 \pm 0,02 \mathrm{~b}$ & $3,78 \pm 0,01 \mathrm{c}$ & $64,24 \pm 0,84 \mathrm{c}$ & $12,76 \pm 0,10 \mathrm{a}$ \\
P4 (6\%) & $1,09 \pm 0,02 \mathrm{~b}$ & $3,75 \pm 0,02 \mathrm{~d}$ & $77,15 \pm 1,39 \mathrm{~b}$ & $12,16 \pm 0,71 \mathrm{a}$ \\
P5 (8\%) & $1,23 \pm 0,01 \mathrm{a}$ & $3,73 \pm 0,01 \mathrm{~d}$ & $90,33 \pm 0,67 \mathrm{a}$ & $13,19 \pm 0,35 \mathrm{a}$ \\
\hline
\end{tabular}

Keterangan: Huruf yang sama pada kolom yang sama menunjukkan perlakuan tidak berbeda nyata $(\mathrm{P}>0,05)$.

\section{Total Asam Laktat}

Hasil analisis ragam menunjukkan bahwa penambahan tepung ubi jalar ungu pada health-promoting yogurt berpengaruh nyata $(\mathrm{P}<0,05)$ terhadap total asam laktat health-promoting yogurt. Nilai total asam menurut SNI (dihitung sebagai asam laktat) sebesar 0,5\%-2,0\%, sehingga healthpromoting yogurt dengan semua perlakuan telah memenuhi standar.

Strain probiotik L. rhamnosus SKG34 merupakan kelompok BAL homofermentatif yakni BAL yang menghasilkan asam laktat sebagai produk utama dari fermentasi gula (Sujaya, dkk., 2008). Pada proses fermentasi, bakteri asam laktat (BAL) akan menghasilkan asam laktat dengan memecah sumber karbohidrat yakni laktosa yang terdapat pada susu dan gula yang terdapat pada tepung ubi jalar ungu. Sehingga semakin banyak jumlah penambahan tepung ubi jalar ungu, maka asam laktat yang terbentuk akan semakin banyak, karena semakin banyak jumlah gula yang dipecah oleh BAL. Asam laktat yang dihasilkan ini menyebabkan penurunan $\mathrm{pH}$ susu atau meningkatkan keasaman susu. Asam laktat juga memberikan ketajaman rasa, rasa asam, dan menimbulkan aroma khas pada yogurt (Koswara, 2009).

\section{Derajat Keasaman (pH)}

Hasil analisis ragam menunjukkan bahwa penambahan tepung ubi jalar ungu pada health-promoting yogurt berpengaruh nyata $(\mathrm{P}<0,05)$ terhadap $\mathrm{pH}$ health-promoting yogurt. Pada proses fermentasi BAL homofermentatif, akan dihasilkan asam laktat sebagai produk utama dari fermentasi gula. Total asam laktat pada health-promoting yogurt dengan perlakuan tanpa penambahan tepung ubi jalar ungu hingga dengan perlakuan penambahan tepung ubi jalar ungu $8 \%$ mengalami peningkatan sehingga menyebabkan nilai $\mathrm{pH}$ health-promoting yogurt menurun dikarenakan semakin banyak jumlah gula yang diubah menjadi asam laktat oleh BAL.

\section{Aktivitas Antioksidan}

Hasil analisis ragam menunjukkan bahwa penambahan tepung ubi jalar ungu 
pada health-promoting yogurt berpengaruh nyata $(\mathrm{P}<0,05)$ terhadap aktivitas antioksidan health-promoting yogurt. Ubi jalar mengandung pigmen antosianin pada daging dan kulitnya yang memberikan warna ungu pekat (Timberlake dan Bridle, 1982). Pakorny, dkk. (2001) menjelaskan bahwa pigmen antosianin pada ubi jalar ungu mempunyai aktivitas antioksidan. Penambahan tepung ubi jalar ungu berbanding lurus terhadap aktivitas antioksidan pada setiap perlakuan, sehingga semakin banyak penambahan tepung ubi jalar ungu, semakin besar aktivitas antioksidan dari health-promoting yogurt.

Aktivitas antioksidan juga dipengaruhi oleh peningkatan jumlah total BAL yakni $L$. rhamnosus SKG34 pada health-promoting yogurt, sehingga health-promoting yogurt dengan perlakuan tanpa penambahan tepung ubi jalar memiliki aktivitas antioksidan sebesar $14,51 \%$. Kemampuan BAL untuk memecah protein (proteolitik) menjadi peptida (bioactive peptides) yang memiliki aktivitas antioksidan juga berkaitan dengan peningkatan aktivitas antioksidan pada yogurt (Virtanen, dkk, 2006). Nocianitri (2016) menjelaskan bahwa L. rhamnosus SKG34 dapat menghambat peroksidasi lipid, mengikat ion logam $\mathrm{Fe}\left(\mathrm{Fe}^{2+}\right)$, menangkap radikal hidroksil $(\mathrm{OH})$, dan memiliki aktivitas ezim superoxida dismutase (SOD) hingga $66,15 \%$.

\section{Total BAL}

Hasil analisis ragam menunjukkan bahwa penambahan tepung ubi jalar ungu pada health-promoting yogurt berpengaruh tidak nyata $(\mathrm{P}>0,05)$ terhadap total $\mathrm{BAL}$ health-promoting yogurt. Indratiningsih, dkk (1981), jumlah minimal sel probiotik hidup untuk dapat berperan sebagai agensi pemacu kesehatan adalah $10^{6} \mathrm{CFU} / \mathrm{ml}$. Chandan dan Shahani (1993), menambahkan bahwa jumlah mikroba aktif yang harus terdapat dalam health-promoting yogurt paling sedikit $10^{7}$ $\mathrm{CFU} / \mathrm{ml}$. Health-promoting yogurt dengan perlakuan tanpa penambahan tepung ubi jalar hingga penambahan tepung ubi jalar ungu sebesar $8 \%$ sudah memenuhi syarat minimal sebagai bahan pangan yang mengandung probiotik.

Total BAL mempengaruhi total asam dan $\mathrm{pH}$ karena BAL memecah karbohidrat dari susu dan tepung ubi jalar menjadi asam laktat yang ditandai dengan menurunnya $\mathrm{pH}$. Semakin banyak asam laktat yang dihasilkan, semakin rendah nilai $\mathrm{pH}$ pada healthpromoting yogurt. Penelitian Sujaya, dkk., (2008), menunjukkan bahwa strain $L$. rhamnosus SKG 34 merupakan salah satu strain yang diisolasi dari susu kuda liar Sumbawa yang menunjukkan pertumbuhan baik pada model getah lambung $\mathrm{pH} 3$, sehingga strain ini dapat bertahan pada $\mathrm{pH}$ rendah. Total BAL tidak dipengaruhi oleh 
nilai aktivitas antioksidan dari penambahan tepung ubi jalar ungu.

\section{Evaluasi Sensori}

Evaluasi sifat sensoris healthpromoting yogurt dilakukan dengan uji hedonik terhadap warna, tekstur, aroma, rasa dan penerimaan keseluruhan serta uji skoring terhadap warna, tekstur, dan rasa. Nilai rata- rata uji hedonik terhadap warna, tekstur, aroma, rasa dan penerimaan keseluruhan health-promoting yogurt dapat dilihat pada Tabel 3 serta nilai rata-rata uji skoring terhadap warna, tekstur, dan rasa dapat dilihat pada pada Tabel 4, sedangkan nilai rata-rata uji keadaan dapat dilihat pada Tabel 5 .

Tabel 3. Nilai rata-rata uji sensori warna dan tekstur health-promoting yogurt.

\begin{tabular}{ccccc}
\hline Perlakuan & Skoring Warna & Hedonik Warna & Skoring Tekstur & Hedonik Tekstur \\
\hline P1 $(0 \%)$ & $1,00 \mathrm{e}$ & $4,47 \mathrm{~d}$ & $2,47 \mathrm{~d}$ & $4,40 \mathrm{~b}$ \\
P2 $(2 \%)$ & $1,67 \mathrm{~d}$ & $4,47 \mathrm{~d}$ & $2,67 \mathrm{~d}$ & $4,80 \mathrm{~b}$ \\
P3 $(4 \%)$ & $2,60 \mathrm{c}$ & $5,13 \mathrm{c}$ & $3,47 \mathrm{c}$ & $5,47 \mathrm{a}$ \\
P4 $(6 \%)$ & $3,60 \mathrm{~b}$ & $5,87 \mathrm{~b}$ & $4,20 \mathrm{~b}$ & $5,73 \mathrm{a}$ \\
P5 (8\%) & $4,00 \mathrm{a}$ & $6,47 \mathrm{a}$ & $4,67 \mathrm{a}$ & $5,87 \mathrm{a}$ \\
\hline
\end{tabular}

Keterangan : Huruf yang sama dibelakang nilai rata-rata pada kolom yang sama menunjukkan perlakuan berbeda tidak nyata $(\mathrm{P}>0,05)$.

Kriteria hedonik : 1 (sangat tidak suka), 2 (tidak suka), 3 (agak tidak suka), 4 (biasa), 5 (agak suka), 6 (suka) dan 7 (sangat suka).

Nilai skoring warna: 1 (putih); 2 (putih kemerahmudaan); 3 (merah muda); 4 (merah muda keunguan); 5 (ungu).

Nilai skoring tekstur: 1 (sangat tidak kental); 2 (tidak kental); 3 (agak kental); 4 (kental); 5 (sangat kental).

Tabel 4. Nilai rata-rata uji sensori rasa, aroma dan penerimaan keseluruhan health-promoting yogurt.

\begin{tabular}{ccccc}
\hline Perlakuan & Skoring Rasa & Hedonik Rasa & Hedonik Aroma & $\begin{array}{c}\text { Penerimaan } \\
\text { Keseluruhan }\end{array}$ \\
\hline P1 (0\%) & $3,53 \mathrm{c}$ & $4,33 \mathrm{a}$ & $4,73 \mathrm{a}$ & $4,73 \mathrm{a}$ \\
P2 (2\%) & $3,93 \mathrm{bc}$ & $4,47 \mathrm{a}$ & $5,07 \mathrm{a}$ & $5,00 \mathrm{a}$ \\
P3 (4\%) & $4,40 \mathrm{ab}$ & $4,67 \mathrm{a}$ & $5,13 \mathrm{a}$ & $5,13 \mathrm{a}$ \\
P4 (6\%) & $4,87 \mathrm{a}$ & $4,13 \mathrm{a}$ & $4,87 \mathrm{a}$ & $5,33 \mathrm{a}$ \\
P5 (8\%) & $4,87 \mathrm{a}$ & $4,47 \mathrm{a}$ & $4,87 \mathrm{a}$ & $5,07 \mathrm{a}$ \\
\hline
\end{tabular}

Keterangan : Huruf yang sama dibelakang nilai rata-rata pada kolom yang sama menunjukkan perlakuan berbeda tidak nyata $(\mathrm{P}>0,05)$.

Kriteria hedonik : 1 (sangat tidak suka), 2 (tidak suka), 3 (agak tidak suka), 4 (biasa), 5 (agak suka), 6 (suka) dan 7 (sangat suka).

Nilai skoring rasa: 1 (hambar); 2 (tidak asam); 3 (agak asam); 4 (asam); 5 (sangat asam). 
Tabel 5. Nilai rata-rata uji keadaan menurut SNI 2981:2009 tentang yogurt.

\begin{tabular}{ccccc}
\hline Perlakuan & Penampakan & Bau & Rasa & Konsistensi \\
\hline P1 $(0 \%)$ & Normal & Normal & Normal & Homogen \\
P2 $(2 \%)$ & Normal & Normal & Normal & Homogen \\
P3 $(4 \%)$ & Normal & Normal & Normal & Homogen \\
P4 $(6 \%)$ & Normal & Normal & Normal & Homogen \\
P5 $(8 \%)$ & Normal & Normal & Normal & Homogen \\
\hline
\end{tabular}

Keterangan: penampakan cairan kental-padat (normal); bau khas yogurt (normal); rasa khas yogurt (normal); konsistensi padatan tidak terpisah dengan cairan (homogen).

\section{Warna}

Hasil sidik ragam menunjukkan bahwa penambahan tepung ubi jalar ungu pada health-promoting yogurt berpengaruh nyata $(\mathrm{P}<0,05)$ terhadap uji hedonik warna healthpromoting yogurt dan uji skoring warna health-promoting yogurt. Semakin tinggi penambahan tepung ubi jalar maka warna dari health-promoting yogurt yang dihasilkan akan lebih merahmuda keunguan, hal ini disebabkan karena adanya pigmen antosianin yang dapat berubah warna karena pengaruh $\mathrm{pH}$, semakin asam maka semakin merah, semakin banyak penambahan tepung ubi jalar maka warna yang dihasilkan akan semakin pekat (berwarna merah muda keunguan). Mahmudatussa'adah, $\quad$ dkk. menjelaskan bahwa warna esktrak antosianin cenderung berubah seiring dengan kenaikan pH 1-14 dari warna merah, ungu, biru, hijau, dan kuning. P1 memiliki warna putih karena tidak ditambahkan tepung ubi jalar ungu, P2 dan P3 memiliki warna sedikit kemerahmudaan hingga merah muda, sedangkan P4 dan P5 memiliki warna merah muda pekat dan merah muda keunguan.
Nilai rata-rata pada uji hedonik warna health-promoting yogurt menunjukkan bahwa nilai rata-rata tertinggi diperoleh dengan penambahan tepung ubi jalar ungu 8\% (P5) dengan kriteria suka, sedangkan nilai rata-rata terendah diperoleh pada health-promoting yogurt tanpa penambahan tepung ubi jalar (P1), dengan kriteria biasa serta berbeda tidak nyata dengan P2. Tingkat kesukaan panelis terhadap warna health-promoting yogurt dapat dipengaruhi oleh penambahan tepung ubi jalar karena pigmen antosianin yang menghasilkan perubahan warna pada produk.

\section{Tekstur, Penampakan, dan Konsistensi}

Hasil sidik ragam menunjukkan bahwa penambahan tepung ubi jalar ungu pada health-promoting yogurt berpengaruh nyata $(\mathrm{P}<0,05)$ terhadap uji hedonik dan uji skoring tekstur health-promoting yogurt. Semakin banyak penambahan tepung ubi jalar ungu, semakin kental dan lembut tekstur healthpromoting yogurt yang dihasilkan karena pada ubi jalar ungu terdapat kandungan karbohidrat yang dapat berfungsi sebagai bahan pengisi (filling agent) sehingga didapatkan tekstur health-promoting yogurt 
yang kental, lembut, serta homogen. Dalam pembuatan health-promoting yogurt diperlukan bahan kering bukan lemak sebagai bahan pengisi yang dapat mempengaruhi tekstur health-promoting yogurt seperti polisakarida, gelatin, dan agar (Campbell dan Marshall, 2000).

Tingkat kesukaan panelis terhadap tekstur health-promoting yogurt dipengaruhi oleh kekentalan dari health-promoting yogurt tersebut dimana semakin benyak penambahan tepung ubi jalar maka tekstur yang dihasilkan semakin kental dan lembut. Menurut Widodo (2002) yogurt yang dibuat dengan susu murni memiliki $12 \%$ total padatan dan dapat diterima dengan baik oleh panelis dengan penambahan padatan hingga $18 \%$.

Hasil pengujian mutu health-promoting yogurt menunjukkan bahwa semua perlakuan memiliki tekstur dan konsistensi yang homogen, dengan ciri-ciri cairan tidak terpisah dengan padatannya, serta memiliki penampakan yang normal, dengan ciri-ciri cairan kental-padat, sehingga healthpromoting yogurt dengan semua perlakuan sesuai dengan SNI.

\section{Rasa}

Hasil sidik ragam menunjukkan bahwa penambahan tepung ubi jalar ungu pada health-promoting yogurt berpengaruh tidak nyata $(\mathrm{P}>0,05)$ terhadap uji hedonik rasa health-promoting yogurt dan berpengaruh nyata $(\mathrm{P}<0,05)$ terhadap uji skoring rasa health-promoting yogurt. Nilai rata-rata dari uji skor rasa health-promoting yogurt tertinggi diperoleh pada health-promoting yogurt dengan penambahan tepung ubi jalar ungu 6\% (P4) dan 8\% (P5) dengan kriteria asam, sedangkan nilai rata-rata terendah diperoleh pada health-promoting yogurt tanpa benambahan tepung ubi jalar (P1) dengan kriteria agak asam.

Nilai rata-rata uji hedonik rasa healthpromoting yogurt tertinggi diperoleh pada health-promoting yogurt dengan penambahan tepung ubi jalar 4\% (P3) dengan kriteria agak suka. Penambahan tepung ubi jalar ungu pada health-promoting yogurt tidak mempengaruhi tingkat kesukaan panelis terhadap rasa health-promoting yogurt, karena rasa yang ditimbulkan dari health-promoting yogurt dominan rasa asam, sehingga panelis menilai semua perlakuan memiliki karakteristik rasa asam yang hampir sama.

Hasil pengujian mutu health-promoting yogurt menunjukkan bahwa health-promoting yogurt dengan semua perlakuan memiliki rasa yang normal, dengan ciri-ciri khas health-promoting yogurt, sehingga healthpromoting yogurt dengan semua perlakuan sesuai dengan SNI.

\section{Aroma}

Hasil analisis sidik ragam menunjukkan bahwa penambahan tepung ubi jalar ungu pada health-promoting yogurt berpengaruh tidak nyata $(\mathrm{P}>0,05)$ terhadap 
nilai rata-rata uji hedonik aroma healthpromoting yogurt. Nilai rata-rata uji hedonik aroma health-promoting yogurt memiliki kriteria agak suka dari semua perlakuan. Hal ini dikarenakan aroma asam yang kuat dan khas pada health-promoting yogurt masih dominan yang merupakan hasil pemecahan karbohidrat dari susu dan tepung ubi jalar menjadi asam laktat sehingga semua perlakuan memiliki karakter aroma yang seragam.

Hasil pengujian mutu health-promoting yogurt bahwa health-promoting yogurt dengan semua perlakuan memiliki bau yang normal, dengan ciri-ciri khas healthpromoting yogurt, sehingga health-promoting yogurt dengan semua perlakuan sesuai dengan SNI.

\section{Penerimaan Keseluruhan}

Hasil sidik ragam menunjukkan bahwa penambahan tepung ubi jalar ungu pada health-promoting yogurt berpengaruh tidak nyata $(\mathrm{P}>0,05)$ terhadap penerimaan keseluruhan health-promoting yogurt. Nilai rata-rata tertinggi diperoleh pada healthpromoting yogurt dengan penambahan tepung ubi jalar 6\% (P4) dengan kriteria agak suka, sedangkan nilai rata-rata terendah diperoleh pada health-promoting yogurt tanpa penambahan tepung ubi jalar (P1). Nilai ratarata kesukaan keseluruhan tersebut menunjukkan bahwa health-promoting yogurt dengan penambahan tepung ubi jalar dapat diterima dengan cukup baik oleh panelis.

\section{KESIMPULAN DAN SARAN}

\section{Kesimpulan}

Berdasarkan hasil penelitian yang telah dilakukan dapat diambil kesimpulan sebagai berikut:

1. Penambahan tepung ubi jalar ungu yang berbeda berpengaruh terhadap total asam, $\mathrm{pH}$, aktivitas antioksidan, warna, tekstur, serta rasa health-promoting yogurt.

2. Penambahan tepung ubi jalar ungu sebanyak $8 \%$ menghasilkan karakteristik terbaik pada pembuatan health-promoting yogurt dengan kriteria total asam laktat 1,23\%, pH 3,73, aktivitas antioksidan 90,33\%, total BAL 13,19 Log CFU/ml, warna merah muda dan tekstur sangat kental disukai, rasa agak asam dan biasa, dan aroma dan penerimaan keseluruhan agak disukai.

\section{Saran}

Berdasarkan penelitian di atas disarankan untuk:

1. Melakukan penelitian lebih lanjut mengenai umur simpan health-promoting yogurt dengan penambahan tepung ubi jalar ungu sebanyak $8 \%$.

2. Health-promoting yogurt dengan karakteristik terbaik dapat dilakukan dengan penambahan tepung ubi jalar ungu sebanyak $8 \%$. 


\section{DAFTAR PUSTAKA}

Anonimus. 2009. SNI No.2981:2009 Tentang Yogurt. Badan Standardisasi Nasional. Jakarta.

Campbell, J.R. dan R.T. Marshall. 2000. The Science of Providing Milk for Men. McGraw Hill Book Co. Inc. New York

Gomez and Gomez. 1995. Review of the Progress of Dairy Science: Genetics of Lactic Acid Bacteria. Journal of Dairy Review 48: 363-376.

Helferich, W. and D.C., Westhoff, 1980. All About Yogurt. Prentice-Hall Inc. Westport, Conecticut.

Husnah, S. 2010. Pembuatan Tepung Ubi Jalar Ungu (Ipomea batatas varietas Ayamurasaki) dan Aplikasinya dalam Pembuatan Roti Tawar. Skripsi. Institut Pertanian Bogor. Bogor.

Koswara, S. 2009. Teknologi Pembuatan Yogurt. eBookPangan.

Koswara, S. 2013. Pengolahan Ubi Jalar. Seafast Center IPB. eBookPangan.

Lingga, P. 1995. Bertanam Ubi-ubian. Penebar Swadaya. Jakarta.

Mahmudatussa'adah, A., D. Fardiaz, N. Andarwulan, F. Kusnandar, 2014. Karakteristik Warna dan Aktivitas Antioksidan Ubi Jalar Ungu. Jurnal Tekno dan Industri Pangan Vol. 25 Hal. 176-184. Bogor.

Nocianitri, K.A. 2016. Sifat Fungsional Lactobacillus rhamnosus SKG34 dan Lactobacillus rhamnosus FBB42 Sebagai Antioksidan dan Penurun Kolesterol Darah Secara In Vivo. Disertasi. Fakultas Pertanian Universitas Udayana. Denpasar.

Pakorny, J., Yanishlieva N., Gordon M. 2001. Antioxidant in Food: Practical and Application. CRC Press. New York.
Patrignani, F., L. Iucci, R. Lanciotti, M. Vallicelli, J. M. Mathara, W. H. Holzapfel, dan M. E. Guerzoni. Effect of High-Pressure Homogenization, Nonfat Milk Solids, and Milkfat on the Technological Performance of a Functional Strain for the Production of Probiotic Fermented Milks.

Pelczar, M.J. \&amp; E.C.S. Chan, 1986, Penerjemah, Ratna Siri Hadioetomo dkk. Dasar-Dasar Mikrobiologi 1, Universitas Indonesia Press. Jakarta.

Rahmawati, I. R., Z. Elok, dan S. Ella. 2015. Evaluasi Pertumbuhan Isolat Probiotik (L. Casei dan $L$. Plantarum) dalam Medium Fermentasi Berbasih Ubi Jalar (Ipomea batatas) Selama Proses Fermentasi (Kajian Jenis Isolat dan Jenis Tepung Ubi jalar). Jurnal Aplikasi Teknologi Pangan vol.4. Universitas Brawijaya. Malang.

Siregar, M.N.H., Lilik E.R., dan Djalal R. 2014. The Effect of Different Concentration of Culture and Incubation Time at Room Temperature on $\mathrm{pH}$, Viscocity, Acidity Content, and Total Plate Count (TPC) Set Yogurt. Universitas Brawijaya. Malang

Sujaya, I N., A. A. Nanak A., N. P. Desy A., Y. Ramona, dan W. Redi A. 2009. Survival of Lactobacillus sp SKG34 in Fermented Milk. International Seminar of Indonesian Society for Microbiology, Bogor Indonesia 4-7 Oct. 2009.

Sujaya, I. N., Y. Ramona, N.M. Utami D., N.I.P. Suariani, N.P. Widarini, K.A. Nocianitri, dan N.W. Nursini. 2008. Isolation and Characterization of Lactic Acid Bacteria from Sumbawa Mare Milk. J. Vet. 9:52-59.

Suryani, Y., A. B. Oktavia dan S. Umniyati. 2010. Isolasi dan Karakterisasi 
Bakteri Asam Laktat dari Limbah Kotoran Ayam sebagai Agensi Probiotik dan Enzim Kolesterol Reduktase. Biologi dan Pengembangan Profesi Pendidik Biologi. Biota. 12 (3): 177-185.

Tamime, A.Y. dan R.K. Robinson. 2007. Yogurt: Science and Tecnology Third Edition. Woodhead Publishing. Cambridge.

Timberlake CF, Bridle P. 1982. The Chemistry of Anthocyanins. Dalam: Markakis, P (Ed), Anthocyanins as Food Colors. Harcourt Brace Jovanovich, New York.

Virtanen, T., Pihlanto, A., Akkanen, S., Korhonen, H. 2006. Development of antioxidant activity in milk whey during fermentation with lactic acid bacteria. Biotechnology and Food Research, MTT Agrifood Research Finland, Jokioinen, Finland.

Widodo, W. 2002. Bioteknologi Fermentasi Susu. Pusat Pengembangan Bioteknologi Universitas Muhammadiyah Malang. Malang.

Winarno, F.G., W. Winaryo, dan W. Widjajanto. 2003. Flora Usus dan Yogurt. Cetakan satu. M-BRIO Press: Bogor.

Yuliansyah, M. H. N. 2014. Potensi Isolat Lactobacillus sp SKG34 Dari Susu Kuda Liar Sebagai Starter Pembuatan Yogurt. Skripsi. Fakultas Teknologi pertanian Universitas Udayana. Denpasar. 